\title{
Physiological implications of altitude training for endurance performance at sea level: a review
}

\author{
Damian M Bailey, Bruce Davies
}

\begin{abstract}
Summary
Acclimatisation to environmental hypoxia initiates a series of metabolic and musculocardiorespiratory adaptations that influence oxygen transport and utilisation. Whilst it is clear that adequate acclimatisation, or better still, being born and raised at altitude, is necessary to achieve optimal physical performance at altitude, scientific evidence to support the potentiating effects after return to sea level is at present equivocal. Despite this, elite athletes continue to spend considerable time and resources training at altitude, misled by subjective coaching opinion and the inconclusive findings of a large number of uncontrolled studies. Scientific investigation has focused on the optimisation of the theoretically beneficial aspects of altitude acclimatisation, which include increases in blood haemoglobin concentration, elevated buffering capacity, and improvements in the structural and biochemical properties of skeletal muscle. However, not all aspects of altitude acclimatisation are beneficial; cardiac output and blood flow to skeletal muscles decrease, and preliminary evidence has shown that hypoxia in itself is responsible for a depression of immune function and increased tissue damage mediated by oxidative stress. Future research needs to focus on these less beneficial aspects of altitude training, the implications of which pose a threat to both the
\end{abstract} fitness and the health of the elite competitor.

Paul Bert was the first investigator to show that acclimatisation to a chronically reduced inspiratory partial pressure of oxygen $\left(\mathrm{P}_{\mathrm{I}} \mathrm{O}_{2}\right)$ invoked a series of central and peripheral adaptations that served to maintain adequate tissue oxygenation in healthy skeletal muscle, ${ }^{1}$ physiological adaptations that have been subsequently implicated in the improvement in exercise performance during altitude acclimatisation. However, it was not until half a century later that scientists suggested that the additive stimulus of environmental hypoxia could potentially compound the normal physiological adaptations to endurance training and accelerate performance improvements after return to sea level. This has stimulated an exponential increase in scientific research, and, since 1984,

School of Applied Sciences, University of Glamorgan, Pontypridd, Mid-Glamorgan, United Kingdom D M Bailey B Davies

Correspondence to: D M Bailey.

Accepted for publication 8 May 1997
22 major reviews have summarised the physiological implications of altitude training for both aerobic and anaerobic performance at altitude and after return to sea level. Of these reviews, only eight have specifically focused on physical performance changes after return to sea level, ${ }^{2-9}$ the most comprehensive of which was recently written by Wolski et al. ${ }^{9}$

Few reviews have considered the potentially less favourable physiological responses to moderate altitude exposure, which include decreases in absolute training intensity, ${ }^{10} \mathrm{de}-$ creased plasma volume, ${ }^{11}$ depression of haemopoiesis and increased haemolysis, ${ }^{12}$ increases in sympathetically mediated glycogen depletion at altitude, ${ }^{13}$ and increased respiratory muscle work after return to sea level. ${ }^{14}$ In addition, there is a risk of developing more serious medical complications at altitude, which include acute mountain sickness, pulmonary oedema, cardiac arrhythmias, and cerebral hypoxia. ${ }^{15}$ The possible implications of changes in immune function at altitude have also been largely ignored, despite accumulating evidence of hypoxia mediated immunosupression. ${ }^{16}$

In general, altitude training has been shown to improve performance at altitude, whereas no unequivocal evidence exists to support the claim that performance at sea level is improved. Table 1 summarises the theoretical advantages and disadvantages of altitude training for sea level performance.

This review summarises the physiological rationale for altitude training as a means of enhancing endurance performance after return to sea level. Factors that have been shown to affect the acclimatisation process and the subsequent implications for exercise performance at sea level will also be discussed.

Studies were located using five major database searches, which included Medline, Embase, Science Citation Index, Sports Discus, and Sport, in addition to extensive hand searching and cross referencing. All published English studies, dating back from the present day to 1956 , that included physiological measurements during exercise before and after hypoxic training were incorporated in the overall analysis. Ninety one investigations were selected, which included 772 hypoxically trained experimental and 209 normoxically trained control subjects.

The investigations were subdivided according to whether a normoxically trained control group was incorporated into the experimental design. Other classifications were made depending on the characteristics of the hypoxic stimulus, which included type (normobaric or hypobaric hypoxia; continuous or intermittent), duration, and magnitude (calculated ambient $\mathrm{PO}_{2}$ ), and timing of physiological testing after the descent to sea level.

The continued popularity of altitude training has been influenced by two factors. Firstly, hypoxia in itself increases blood haemoglobin (Hb) concentration, which has been shown to improve endurance performance. Secondly, several of the best endurance runners in the world have originated from East African countries that are based at altitude $(1500-2000 \mathrm{~m})$. Is it possible that either living and/or training at 
Table 1 Physiological changes during altitude acclimatisation in native lowlanders; time course and theoretical implications for exercise performance at sea level

\begin{tabular}{llll}
\hline $\begin{array}{l}\text { Physiological advantages } \\
\text { time }\end{array}$ & Physiological disadvantages & Response time \\
\hline $\begin{array}{c}\text { Increased free fatty acid } \\
\text { mobilisation }\end{array}$ & Weeks & Increased ventilation & Immediate \\
$\begin{array}{c}\text { Increased haemoglobin } \\
\text { Increased capillarity }\end{array}$ & $\begin{array}{l}\text { Days } \\
\text { Months/ } \\
\text { years? }\end{array}$ & $\begin{array}{l}\text { Decreased cardiac output } \\
\text { Decreased blood flow }\end{array}$ & $\begin{array}{l}\text { Days } \\
\text { Days }\end{array}$ \\
$\begin{array}{c}\text { Increased oxidative } \\
\text { enzyme activity }\end{array}$ & Weeks & Immunosupression & $\begin{array}{l}\text { Immediate?/ } \\
\text { days } \\
\text { volume }\end{array}$ \\
Weeks & & $\begin{array}{l}\text { Increased oxidative stress and tissue } \\
\text { damage }\end{array}$ & Immediate \\
Increased dehydration & $\begin{array}{l}\text { Jet lag } \\
\text { Decreased training intensity } \\
\text { Acute mountain sickness } \\
\text { Sunburn due to increased ultraviolet }\end{array}$ & $\begin{array}{l}\text { Immediate } \\
\text { Immediate } \\
\text { Immediate } \\
\text { Days } \\
\text { Immediate }\end{array}$ \\
& & $\begin{array}{l}\text { Catecholamine mediated glycogen } \\
\text { depletion }\end{array}$ & Days-weeks \\
Increased haemolysis & Weeks \\
\hline
\end{tabular}

altitude may contribute to their running success?

\section{Physiological rationale for altitude training}

AUTOLOGOUS BLOOD REINFUSION AND

ENDURANCE PERFORMANCE

One of the most documented physiological adaptations to a reduced $\mathrm{P}_{\mathrm{I}} \mathrm{O}_{2}$ is the increased release of erythropoietin, which causes a transient increase in red blood cell mass. ${ }^{17}$ The implications of secondary polycythaemia to both submaximal and maximal indices of endurance performance have been clearly shown by studies that have artificially induced erythrocythaemia after either autologous blood reinfusion $^{18}$ or subcutaneous injections of recombinant human erythropoietin. ${ }^{1920}$ Table 2 summarises the major research findings. It has been reported that absolute maximal oxygen uptake $\left(\mathrm{V}_{2} \mathrm{MAX}\right)$ values are increased by about $200 \mathrm{ml} / \mathrm{min}$ per $\mathrm{g} / \mathrm{dl}$ increase in $\mathrm{Hb}$, irrespective of the methods by which polycythaemia is induced. ${ }^{21}$

However, the use of blood doping as an ergogenic aid is considered unethical and potentially dangerous and is banned by the International Olympic Committee. ${ }^{22}$

PHYSIOLOGICAL ADAPTATIONS OF THE NATIVE HIGHLANDER: A SUPERIOR ATHLETE?

Figure 1 illustrates the apparently disproportionate running success of the native highlander. This figure represents data obtained

Table 2 Effects of autologous blood reinfusion on $\dot{V}_{O_{2}} \mathrm{MAX}$

\begin{tabular}{llll}
\hline Author/reference & $\begin{array}{l}\text { Volume of blood } \\
\text { reinfused }(\mathrm{ml})\end{array}$ & $\begin{array}{l}\text { Change in } \mathrm{Hb} \text { after } \\
\text { reinfusion (\%) }\end{array}$ & $\begin{array}{l}\text { Change in } \mathrm{VO}_{2} \text { MAX after } \\
\text { reinfusion (\%) }\end{array}$ \\
\hline Ekblom $^{19}$ & 1350 & $+9^{\star}$ & $+8^{\star}$ \\
Celsing $^{21}$ & 2250 & +11 & $+7^{\star \star}$ \\
Buick $^{23}$ & 900 & $+8^{\star \star}$ & $+5^{\star \star}$ \\
Spriet $^{24}$ & 1200 & $\mathrm{NR}$ & $+7^{\star}$ \\
Williams $^{25}$ & 920 & $+7^{\star \star}$ & $\mathrm{NR}$ \\
Goforth $^{26}$ & 760 & $+4^{\star}$ & $+11^{\star \star}$ \\
Robertson $^{27}$ & 750 & $+28^{\star}$ & $+13^{\star}$ \\
Robertson $^{28}$ & 475 & $+16^{\star}$ & $+10^{\star}$ \\
Thompson $^{29}$ & 1000 & $+12^{\star}$ & $+11^{\star}$ \\
Sawka & & $+10^{\star}$ & $+11^{\star}$ \\
Robertson $^{31}$ & 600 & $+16^{\star}$ & $+10^{\star \star}$
\end{tabular}

* Significantly different from before reinfusion $(P<0.05)$.

$\star \star$ Significantly different from before reinfusion $(P<0.01)$.

NR, not reported. from athletes who were born and raised at a median altitude of $2000 \mathrm{~m}$ above sea level. This phenomenon has prompted several comparative investigations into what, if any, physiological adaptations mediated by hypoxia could contribute to their superiority in distance running events. Much interest has focused on the four steps of the oxygen transport system, namely alveolar ventilation, lung diffusion, circulatory oxygen transport, and tissue oxygen extraction. Studies have shown that the native highlander is characterised by a larger pulmonary diffusion capacity ${ }^{32}$ and adaptations in the structural and metabolic organisation of skeletal muscle that result in a tighter coupling between ATP hydrolysis and oxidative phosphorylation. ${ }^{33}$ These are the major factors that facilitate oxygen transport and utilisation. The significance of these adaptations has been elucidated in a series of investigations that have reported higher values for $\mathrm{VO}_{2} \mathrm{MAX},{ }^{34}$ power output, ${ }^{35}$ arterial oxygen saturation, ${ }^{36}$ and cerebral oxygen delivery ${ }^{37}$ during maximal exercise and decreased blood lactate ${ }^{33} 35$ and ammonia concentrations ${ }^{38}$ for a given submaximal work rate.

To what extent these physiological adaptations are acquired as the result of inheritance or hypobaric hypoxia is not well defined. The influence of genetic factors on quantitative oxygen transport was recently investigated in a unique study by Beall et $a l .{ }^{39}$ They identified a major gene that enhances arterial oxygen saturation in sedentary Tibetan natives. The physiological significance of this was shown by Niermeyer et $a l,{ }^{40}$ who concluded that genetic adaptations to hypobaric hypoxia resulted in improved oxygenation and conferred resistance to subacute infantile mountain sickness. These adaptations were more pronounced in a cohort of Tibetan newborns whose ancestors have resided at altitude for 50000 to 100000 years, in comparison with Han newborns whose ancestors had resided at altitude for only 45 years. ${ }^{41}$ In general, these findings would suggest that a lifetime or perhaps generations of altitude exposure are responsible for the biological distinctiveness of the high altitude population.

\section{Altitude training and sea level endurance performance in native lowlanders}

Table 3 summarises the effects of altitude training on sea level endurance performance. The weight of scientific evidence does not support the potentiating effects of altitude training. However, it is becoming clearer that a number of methodological deficiencies may preclude the potential synergistic effects of hypoxia and physical exercise, the physiological implications of which will be discussed in the following sections.

\section{Intensity and duration of the hypoxic stimulus and associated haematological adaptation}

There is still much controversy about the optimal altitude and duration required for athletes to train in an attempt to optimise endurance performance at sea level. Much attention has 


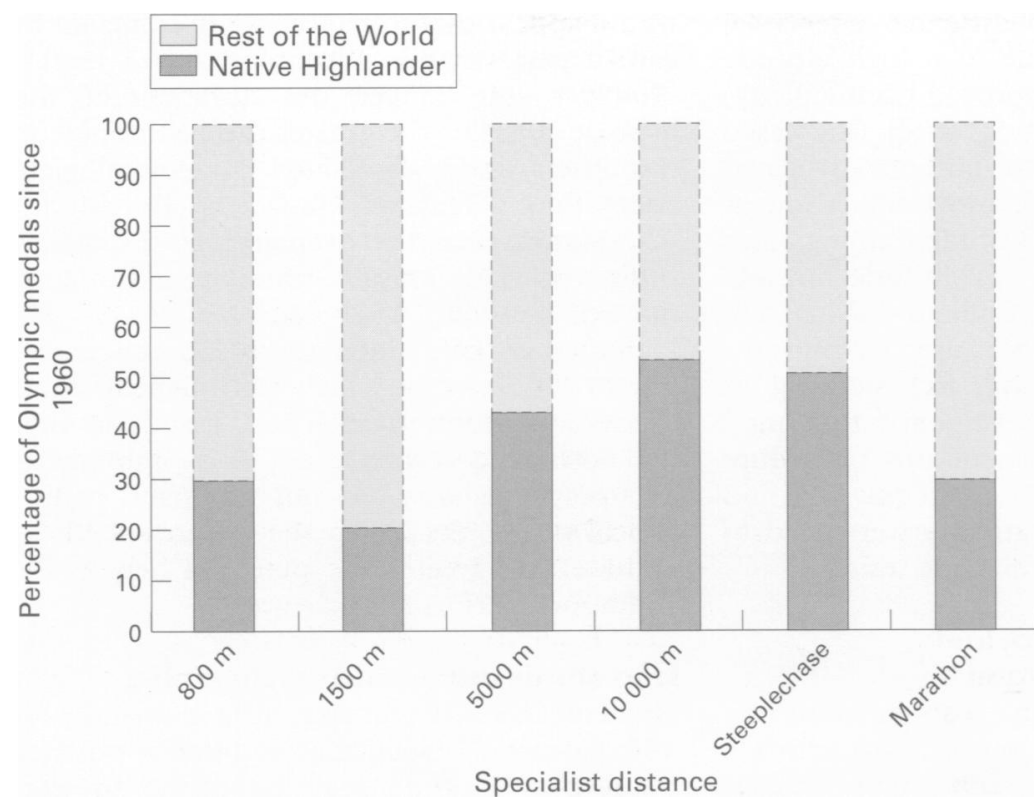

Figure 1 Percentage of Olympic medals for middle and long distance running events won by native highlanders since 1960 .

Table 3 Effects of hypoxic training on sea level endurance performance

\begin{tabular}{llllll}
\hline $\begin{array}{l}\text { Hypoxic } \\
\text { stimulus }\end{array} \quad$ Altitude (m) & $\begin{array}{l}\text { Exposure } \\
\text { time (days) }\end{array}$ & $\begin{array}{l}\text { Time tested } \\
\text { after altitude } \\
\text { (days) }\end{array}$ & $\begin{array}{l}\text { Submaximal } \\
\text { improvement }\end{array}$ & $\begin{array}{l}\text { Change in } \mathrm{VO}_{2} \\
\text { MAX (\%) }\end{array}$ & $\begin{array}{l}\text { Control } \\
\text { group }\end{array}$ \\
\hline
\end{tabular}

\begin{tabular}{|c|c|c|c|c|c|c|}
\hline \multicolumn{7}{|c|}{ Potentiating effects } \\
\hline $\mathrm{CH}^{+2}$ & $1300-2500$ & 28 & 1 & Yes† & $+4 \dagger$ & No \\
\hline $\mathrm{CH}^{43}$ & 1900 & 21 & $1 / 14$ & Yest & NS/NS & No \\
\hline $\mathrm{CH}^{44}$ & $2100-2700$ & 14 & 2 & Yest & NS & No \\
\hline $\mathrm{CH}^{45}$ & 2300 & 23 & $3 / 21$ & Yest & $+8 t /+10 \dagger$ & No \\
\hline $\mathrm{CH}^{46}$ & 2500 & 28 & 7 & ND & $+6 t$ & No \\
\hline $\mathrm{IH}^{47}$ & $3049-4268$ & 23 & $3-4$ & Yes† & NS & No \\
\hline $\mathrm{CH}^{48}$ & 3800 & 35 & 14 & ND & $+14 \dagger$ & No \\
\hline $\mathrm{IH}^{49}$ & 4020 & $21 / 28$ & 1 & Yes† & $+8 \ddagger /+26 \ddagger$ & No \\
\hline $\mathrm{CH}^{50}$ & $1250-2500$ & 28 & 7 & Yest & $+4 \dagger$ & Yes \\
\hline $\mathrm{IH}^{51}$ & 2300 & $21-28$ & 1 & Yest & NS & Yes \\
\hline $\mathrm{IH}^{52}$ & 2300 & 28 & $1-2$ & Yest & ND & Yes \\
\hline $\mathrm{IH}^{53}$ & 4000 & 70 & 1 & Yes† & NS & Yes \\
\hline \multicolumn{7}{|c|}{ No potentiating effects } \\
\hline $\mathrm{CH}^{45}$ & 2300 & 14 & 1 & No & NS & No \\
\hline $\mathrm{CH}^{54}$ & $1695-2700$ & 7 & 4 & ND & NS & No \\
\hline $\mathrm{CH}^{55}$ & 2240 & 20 & $4 / 22$ & ND & $+6 /+9 \star$ & No \\
\hline $\mathrm{CH}^{56}$ & 2300 & 42 & $4-5$ & No & NS & No \\
\hline $\mathrm{CH}^{57}$ & 2300 & 70 & 5 & ND & NS & No \\
\hline $\mathrm{CH}^{58}$ & 2800 & 10 & $2-4$ & No & $+7^{\star}$ & No \\
\hline $\mathrm{CH}^{59}$ & 3090 & 17 & 1 & ND & NS & No \\
\hline $\mathrm{CH}^{60}$ & 3110 & 21 & 7 & ND & $-5^{\star}$ & No \\
\hline $\mathrm{CH}^{61}$ & 4000 & $48-63$ & $2-15$ & No & NS & No \\
\hline $\mathrm{IH}^{62}$ & 4000 & 21 & 1 & ND & NS & No \\
\hline $\mathrm{CH}^{38}$ & 2000 & 14 & $6 / 12$ & ND & NS/NS & Yes \\
\hline $\mathrm{CH}^{63}$ & $1600-1800$ & $18-28$ & 7 & ND & NS & Yes \\
\hline $\mathrm{CH}^{64}$ & 1640 & 28 & 20 & No & NS & Yes \\
\hline $\mathrm{CH}^{65}$ & $1700-2000$ & 28 & 7 & No & NS & Yes \\
\hline $\mathrm{CH}^{66}$ & 2300 & 21 & 1 & No & NS & Yes \\
\hline $\mathrm{IH}^{67}$ & 2250 & 28 & 1 & ND & $+17.5^{\star}$ & Yes \\
\hline $\mathrm{IH}^{67}$ & 3450 & 28 & 1 & ND & $+10.0^{\star}$ & Yes \\
\hline $\mathrm{IH}^{68}$ & 2500 & 28 & 1 & No & NS & Yes \\
\hline $\mathrm{IH}^{69}$ & 2500 & 35 & 1 & ND & NS & Yes \\
\hline $\mathrm{CH}^{70}$ & 2600 & 11 & 1 & ND & NS & Yes \\
\hline $\mathrm{IH}^{71}$ & 3100 & 19 & 6 & No & NS & Yes \\
\hline $\mathrm{IH}^{72}$ & 3345 & 42 & 1 & ND & NS & Yes \\
\hline $\mathrm{IH}^{73}$ & 4020 & 15 & 1 & ND & NS & Yes \\
\hline $\mathrm{IH}^{74}$ & $4100-5700$ & 21 & 1 & ND & NS & Yes \\
\hline $\mathrm{CH}^{75}$ & 4300 & 28 & $1-5$ & ND & NS & Yes \\
\hline
\end{tabular}

$\mathrm{CH}$, Chronic hypobaria; $\mathrm{IH}$, intermittent hypobaria; ND, no data.

$\star$ Level of significance not reported

+ Significantly different from pre-altitude value $(P<0.05)$

$\ddagger$ Significantly different from pre-altitude value $(P<0.01)$

NS, not significantly different from pre-altitude value $(P>0.05)$.

focused on the erythropoietic response to hypoxia and subsequent haematological adaptation. Considering the inverse relationship between $\mathrm{Po}_{2}$ and resting $\mathrm{Hb}$ concentration, ${ }^{76}$ it would seem logical that the higher the athlete can train the better. However, other factors that inhibit exercise performance are exacerbated with a reduction in $\mathrm{Po}_{2}$. Acute mountain sickness presents at altitudes above 2000 to $3000 \mathrm{~m},{ }^{77}$ with the possibility of the elite athlete suffering physiological symptoms at even lower altitudes. ${ }^{15}$ Prolonged exposure to altitudes above $4500 \mathrm{~m}$ has been shown to result in a reduction in muscle mass, the underlying physiological mechanisms for which have been recently reviewed by Kayser. ${ }^{78}$ Finally, the effects of training at a lower $\mathrm{Po}_{2}$ may result in a reduction in work rate, so that detraining may override the potential benefits of altitude acclimatisation. ${ }^{79}$

\section{Hypoxia and detraining}

A recent study has shown that $\dot{\mathrm{VO}}_{2} \mathrm{MAX}$ is significantly reduced at an altitude as low as $610 \mathrm{~m}$ above sea level in elite endurance athletes. ${ }^{80}$ This is a phenomenon peculiar to about $50 \%$ of trained subjects, with $\dot{\mathrm{V}}_{2} \mathrm{MAX}$ values of above $65 \mathrm{ml} / \mathrm{kg}$ per $\min$ or 4 litres/min. ${ }^{81}$ These elite athletes develop more severe levels of arterial hypoxaemia during maximal and submaximal exercise than sedentary controls both under normoxic and hypoxic conditions. ${ }^{82} 83$ Several mechanisms have been proposed to explain these findings, which include hypoventilation, venoarterial shunting, ventilation-perfusion inequality, and an alveolar-capillary diffusion limitation. ${ }^{84} 85$

These observations led early investigators to hypothesise that altitude exposure may result in a detraining response. ${ }^{79}$ Daniels and Oldridge ${ }^{57}$ have shown the importance of training intensity at altitude and its effects on sea level performance. They suggested that intermittent exposures to altitudes of 2300 to 3300 $\mathrm{m}$ and sea level optimised the balance between hypoxic acclimatisation and training intensity. Despite the experimental limitations of a single group design, two world records and 12 personal best times were recorded by athletes on return to sea level, which presented a reasonable endorsement for such an approach. However, from our experience, it is equally possible to have expected similar improvements in a control group training at sea level. ${ }^{64}$

The detraining effect induced during chronic exposure to hypobaric hypoxia has been quantified in a sequence of studies by Levine et al. $^{425068}$ In their most recent study, ${ }^{50}$ 39 competitive runners were randomly assigned to four weeks of (a) living high $(2500 \mathrm{~m})$ and training low $(1250 \mathrm{~m}),(b)$ living high $(2500 \mathrm{~m})$ and training high $(2500 \mathrm{~m})$, or $(c)$ living low $(150 \mathrm{~m})$ and training low $(150 \mathrm{~m})$. They showed that, although $\dot{\mathrm{VO}}_{2} \mathrm{MAX}$ values significantly improved $5 \mathrm{~km}$ race performance times by $4 \%$ in the two altitude trained groups, the running velocity that corresponded to $\dot{\mathrm{V}}_{2} \mathrm{MAX}$ and the ventilatory threshold at sea level were significantly improved only in the group that lived high and trained low. An unusual finding was that $5 \mathrm{~km}$ performance time was 31 seconds slower in the sea level control group, which would suggest that the training stimulus was not absolutely controlled during the experimental period. Nevertheless, it was 
concluded that the potentiating effects of altitude training were due to a high altitude acclimatisation effect (improved haematology) and a low altitude training effect (increased training intensity). Thus the authors advocated the practice of living high and training low as the optimal approach to altitude training. This has popularised the use of "altitude houses" recently developed in Finland which are portable hypobaric chambers used by elite athletes, who alternate living and sleeping at simulated altitude with normobaric training. ${ }^{86}$ However, the effectiveness of this procedure should at present be considered equivocal, and further scientific investigation is warranted to endorse this approach to altitude training.

\section{Concept of a critical $\mathrm{Po}_{2}$ and}

haematological adaptation

Few athletes can afford the costs inherent in a "live high, train low" approach to altitude training. Therefore is it possible that a "threshold" altitude exists that optimises the benefits of haematological acclimatisation and minimises the negative effects of detraining? Weil et $a l^{\beta 7}$ have presented the most comprehensive evidence indicating the existence of such a threshold, albeit in sedentary highland natives (B Levine, personal communication). They identified a biphasic relationship between the arterial partial pressure of oxygen $\left(\mathrm{PaO}_{2}\right)$ and red blood cell mass, and shown a clear inflection point at a "critical" $\mathrm{PaO}_{2}$ of $67 \mathrm{~mm}$ $\mathrm{Hg}$, equivalent to an interpolated arterial oxygen saturation of $92 \%$. This point corresponds to the steeper portion of the oxygen- $\mathrm{Hb}$ dissociation curve. The equivalent $\mathrm{PO}_{2}$ would equate to about $135 \mathrm{~mm} \mathrm{Hg}$, which is comparable with an altitude of $2200-2500 \mathrm{~m}$ above sea level required to stimulate sufficient haemopoiesis at rest to influence endurance performance. ${ }^{4}$ However, it has been shown that the decrement in $\dot{V}_{2}$ MAX measured in hypobaric hypoxia is directly proportional to $\dot{\mathrm{VO}}_{2} \mathrm{MAX}$ measured in normoxia. ${ }^{88}$ This would suggest that elite athletes are more prone to developing arterial hypoxaemia and may gain more benefit haematologically by training at lower altitudes in comparison with sedentary controls. This contention was supported by Ingier et $a l,{ }^{43}$ who showed that three weeks of altitude training at $1900 \mathrm{~m}$ in elite cross country skiers was sufficient to elevate $\mathrm{Hb}$ by $5 \%$ $(\mathrm{P}<0.02)$ and decrease blood lactate concentration during a standardised submaximal test, despite no changes in $\dot{\mathrm{VO}}_{2} \mathrm{MAX}$. However, it should be noted that these authors did not measure their subjects' plasma volumes, and their comments that the polycythaemia was independent of a haemoconcentration remains only speculative. The scarcity of training studies conducted at moderate altitudes of 1500 to $2000 \mathrm{~m}$ in elite athletes does not allow definitive conclusions to be made.

\section{Optimal duration}

Few data are available on the optimal time an athlete should spend training at altitude. On the basis of subjective coaching opinion as opposed to objective scientific evidence, it would appear that three weeks are sufficient to gain a performance advantage at sea level. ${ }^{89}$ However, the longer the duration of the hypoxic stimulus the greater the erythropoietic response and associated haematological adaptation. ${ }^{17}$ This was shown by Berglund, ${ }^{90}$ who summarised the haematological changes during previous altitude training studies conducted between 1829 and $3048 \mathrm{~m}$. He identified a "true" increase in $\mathrm{Hb}$ concentration of $1 \%$ per week, which was independent of a haemoconcentration. Thus, assuming that the detraining response could be minimised and polycythaemia did not approach pathological values, the longer the athlete spends at altitude, the greater the potential benefit for endurance performance.

\section{Iron status during altitude training}

Hypoxia in itself increases iron demand and mobilisation, ${ }^{91}{ }^{92}$ such that endurance athletes training at altitude may be prone to iron deficiency. Lack of this critical erythropoietic factor has been shown to inhibit complete haematological adaptation. ${ }^{93}$ Despite its importance, few studies have actually reported iron status of athletes during their hypoxic exposure. Suboptimal iron stores may account for the vast majority of training studies that have failed to show increases in $\mathrm{Hb}$ concentration and endurance performance on return to sea level after the hypoxic exposure. The differences in iron status may also characterise the highly individualised haematological responses observed during altitude training. ${ }^{43}$

\section{Interval between descent and event}

There is some evidence to suggest that endurance performance is affected by the timing of the descent to sea level after a sojourn to altitude. The general consensus amongst top coaches would suggest that endurance performance is optimised after 14 days at sea level after a bout of altitude training, ${ }^{89}$ yet there is no scientific evidence to support this claim. Suslov $^{94}$ characterised the undulating nature of endurance performance after altitude training. His research was based on over 1000 competitive track results obtained from middle and long distance runners after different periods of altitude training (1300-2500 $\mathrm{m}$ ) and repeated sea level $\dot{\mathrm{VO}}_{2} \mathrm{MAX}$ tests conducted after training at $1800 \mathrm{~m}$. He identified a decrease in competition performance during the first two days at sea level and the first phase of enhanced work capacity occurring between days 3 and 7, followed by a decrease between days 8 and 10 . Performance was shown to continue to improve between days 12 and 13 , with the best results achieved on days 18 to 20 . $\mathrm{He}$ also identified an additional upsurge in performance between days 36 and 48 after altitude. He failed to identify the physiological mechanisms responsible for this phenomenon.

Few studies have tested subjects on more than one occasion after return to sea level. Asahina $e t a b^{5}$ and Faulkner et $a l^{45}$ did not show any significant changes in $\mathrm{VO}_{2} \mathrm{MAX}$ values after either 3 or 22 days at sea level. Ingjer et $a l^{43}$ showed that after a group of elite cross country 


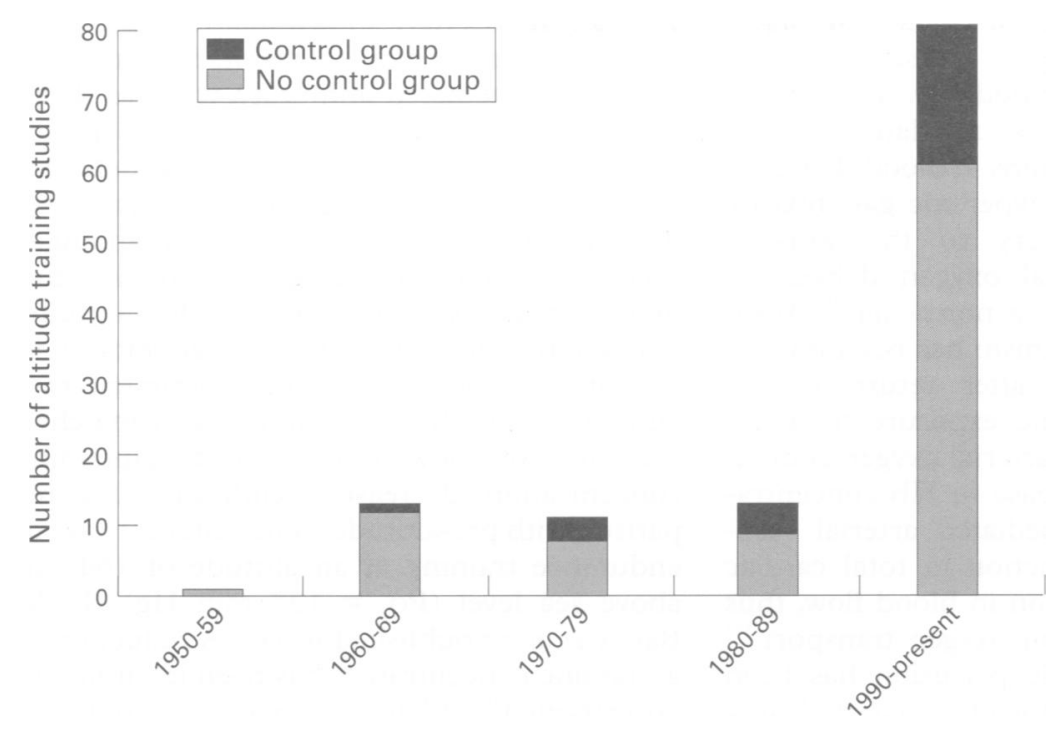

Figure 2 Number of hypoxic training studies conducted with or without a normoxically trained control group since 1950.

skiers had trained for three weeks at an altitude of $1900 \mathrm{~m}$, submaximal blood lactate values were lower than pre-altitude values on day 1 but not day 14 at sea level. The authors concluded that a $0.8 \mathrm{~g} / \mathrm{dl}$ increase in $\mathrm{Hb}$ concentration measured on day 1 was responsible for the observed improvement in submaximal exercise. However, their failure to quantify plasma volume and blood flow changes weakens the validity of their haematological findings. Svedenhag et $a^{8}$ studied a group of Swedish middle distance runners who trained for a period of two weeks at altitude $(2000 \mathrm{~m})$ and were tested after 6 and 12 days on return to sea level. They did not identify any significant changes in $\dot{\mathrm{V}}_{2} \mathrm{MAX}$, maximal oxygen deficit, and submaximal blood lactate values compared with pre-altitude values or between days 6 and 12 at sea level. However, they showed a significant reduction in heart rate, Borg rating of perceived exertion, and plasma ammonia concentration during a standardised submaximal treadmill test, which was more apparent after 12 days at sea level.

The physiological mechanisms responsible for these subtle changes in performance at sea level remain elusive. Intermittent altitude training has been shown to increase the hypoxic ventilatory response in a group of sedentary subjects, whereas an equivalent training programme at sea level had no effect. ${ }^{1495}$ Acute exposure to altitude in the native lowlander may potentiate the hypoxic ventilatory response because of an increased peripheral chemoreceptor sensitivity, which would subsequently increase the work performed by the respiratory muscles. This has not been quantified in the elite athlete but may be implicated in the performance decrements shortly after return to sea level. Plasma volume has been shown to decrease by $25 \%$ during chronic exposure to hypobaric hypoxia ${ }^{11}$ and may take as long as two months to normalise. ${ }^{91}$ After return to sea level, this may remain depressed for six days, ${ }^{96}$ which may also negatively affect performance. Altitude training may also involve considerable travelling time, and the negative impact of jet lag on exercise performance cannot be ignored. ${ }^{97}$

\section{Measurement of the altitude effect independent of training}

Figure 2 shows that, since 1956, only 27 (30\%) of the 91 hypoxic training studies reviewed have incorporated a normoxically trained control group. This makes it impossible to determine whether the physiological changes that occur after a bout of altitude training can be attributed to an improvement in physical conditioning or to the additive effects of hypoxia itself.

To our knowledge, the altitude training studies conducted by Asano et al, ${ }^{53}$ Terrados et $a l^{5152}$ and Levine et $a f^{50}$ would appear to be the only investigations employing a control group that have reported statistically significant improvements in aerobic performance after return to normoxia. Asano et $a p^{3}$ studied ten elite middle to long distance male runners, who trained for a ten week period at the same relative exercise intensity at either sea level or a simulated altitude of $4000 \mathrm{~m}$. After training, there were no improvements in $\dot{\mathrm{V}}_{2} \mathrm{MAX}$ at sea level, yet $10 \mathrm{~km}$ personal best running times improved by about $6 \%(P<0.05)$. Using a one legged training model, Terrados et $a f^{152}$ attributed the potentiating effects of intermittent hypobaric training to increases in citrate synthase activity and myoglobin content. The findings of Levine et a ${ }^{\circ}$ have already been described in this review.

Whilst previous investigations have dealt primarily with aerobic responses to altitude training, there is some evidence to suggest that anaerobic performance is improved on return to sea level. ${ }^{449899}$ Mizuno et al ${ }^{44}$ showed that exercise time to exhaustion after altitude training improved by $17 \%(\mathrm{P}<0.05)$ when compared with pre-altitude values, which they attributed to a $6 \%$ increase $(P<0.05)$ in muscle buffer capacity. However, the validity of these findings is questionable because of the lack of a normoxically trained control group. A well controlled investigation by Martino et al, ${ }^{98}$ which incorporated a performance matched control group based at sea level, investigated the effects of three weeks of altitude training at $2800 \mathrm{~m}$ on anaerobic measures of swimming performance. Sea level sprint performance time over $100 \mathrm{~m}$ was 2.4 seconds quicker in the altitude trained group than the control group $(P<0.05)$. The largest improvements in the altitude trained group were noted in an upper body Wingate test. Peak power output increased by $27.9 \mathrm{~W}$ more than the control group $(P<0.05)$. In a recent investigation, Nummela et al9 showed that ten days of living high $(\sim 2200 \mathrm{~m})$ and training low (sea level) resulted in greater improvements in $400 \mathrm{~m}$ running time $(P<0.05)$ and running velocity at a fixed concentration of blood lactate $(P<0.05)$ when compared with an equivalent programme of sea level training.

However, the vast majority of altitude training studies have not identified performance improvements at sea level. Whilst a decrease in absolute training intensity may be implicated, ${ }^{10}$ 
a decrease in muscle perfusion may also play a contributory role; oxygen transport, determined as a product of blood flow and arterial oxygen concentration is regulated during changes in $\mathrm{PaO}_{2}$. Reductions in blood flow during the inhalation of a hyperoxic gas mixture regulates oxygen delivery to the working muscles, such that total oxygen delivery is similar to that observed in normoxia ${ }^{100}$. Autoregulation of this mechanism has been investigated at altitude and after return to sea level. ${ }^{101} 102$ Whilst chronic exposure to hypobaric hypoxia increased arterial oxygen content as the result of an increase in $\mathrm{Hb}$ concentration, sympathetically mediated arterial vasoconstriction and a reduction in total cardiac output caused a reduction in blood flow, thus preventing an increase in oxygen transport. ${ }^{101}$ This decrease in muscle perfusion has been shown to persist after return to sea level. Using ${ }^{133} \mathrm{Xe}$, blood flow to the vastus lateralis was shown to decrease by up to $39 \%(\mathrm{P}<0.001)$ during submaximal exercise after a three month expedition to $8398 \mathrm{~m}^{102}$

Favier et $a l^{2}$ suggested that the negative findings reported in the literature could, in part, be attributed to the fact that subjects were not fully acclimatised to hypobaric hypoxia. In a unique experiment they used three groups of sedentary high altitude residents, who trained for 30 minutes a day at a constant work rate on a bicycle ergometer, during a six week period. Group 1 trained at a $\mathrm{Po}_{2}$ that was equivalent to an interpolated altitude of $3345 \mathrm{~m}$ at $70 \%$ of $\dot{\mathrm{V}} \mathrm{O}_{2} \mathrm{MAX}$ determined in hypoxia. The remaining two groups trained under normoxic conditions at either the same relative work rate $(70 \%$ of the normoxic $\left.\dot{\mathrm{VO}} \mathrm{O}_{2} \mathrm{MAX}\right)$ or the same absolute work rate $\left(70 \%\right.$ of the hypoxic $\left.\dot{\mathrm{V}} \mathrm{O}_{2} \mathrm{MAX}\right)$ as the hypoxically trained group. An incremental test to exhaustion was performed by all groups in normoxia and hypoxia immediately before and after training in an attempt to ascertain the physiological responses to submaximal and maximal exercise. The authors showed that $\dot{\mathrm{V}} \mathrm{O}_{2} \mathrm{MAX}$ values improved similarly in all groups. However, they suggested that a lower reduction in base excess and bicarbonate stores observed in the hypoxically trained group could only potentially benefit anaerobic metabolism and, although time to exhaustion was not measured, facilitate exercise performance.

\section{Hypoxia and immune function}

Changes in total leucocyte, granulocyte, monocyte, lymphocyte, natural killer cell, and $T$ cell count, helper/suppression cell ratio, cell proliferation in response to mitogens, and serum immunoglobin levels have all been implicated in some form of immunosuppression, which may subsequently cause underperformance in the athlete at sea level. ${ }^{103}$ The additive stress of a reduction in the inspiratory $\mathrm{Po}_{2}$, in conjunction with the extensive training loads employed by athletes at altitude, may explain why some investigators have reported physiological evidence for a less favourable modulation of immune function in vivo during acute and chronic exposure to hypobaric hypoxia. ${ }^{63}$ 104-106
Human studies have shown that chronic exposure to hypobaric hypoxia results in a suppression of cell mediated immunity, whereas B cell function remains unimpaired. ${ }^{16}$ Animal studies have further shown that murine host defences against bacterial pathogens are also impaired in hypoxia. The contributory immunomodulatory role of endogenous glucocorticoids and neuropeptides, which are increased at altitude, may contribute to the observed alterations in immune competence. In an experiment that employed elite distance runners and matched controls, we showed that plasma glutamine concentrations decreased significantly in comparison with pre-altitude values after 20 days of endurance training at an altitude of $1640 \mathrm{~m}$ above sea level $\left(\mathrm{Po}_{2}=135 \mathrm{~mm} \mathrm{Hg}\right)(\mathrm{D} \mathrm{M}$ Bailey et al, unpublished work). A reduction in glutamine concentration has been identified in "overtrained" athletes and may be a contributory factor leading to immunosuppression and underperformance ${ }^{107}$ It is difficult to comment on the physiological mechanisms responsible for these changes, but there is evidence that suggests that chronically elevated levels of circulating catecholamine levels decrease the rate of glutamine transport out of muscle incubated in vitro (Parry-Billings $M$, unpublished data). In addition to this, Wagenmakers ${ }^{108}$ has proposed an alternative mechanism, again related to elevated catecholamine levels observed at altitude. ${ }^{11} \mathrm{He}$ suggested that hypoxia induced glycogen depletion would result in a reduction in the availability of tricarboxylic acid cycle intermediates, in particular 2-oxoglutarate. This is required for the activation of the branched chain amino acid aminotransferase reaction, which ultimately produces glutamine. The implications of the immunosupressive influence of hypobaric hypoxia for endurance performance warrants further investigation in order to elucidate potential mechanisms that may modulate performance after return to sea level.

\section{Reactive oxygen species at altitude}

There is a limited body of evidence suggesting that oxidative injury mediated by free radicals is increased at altitude. ${ }^{109-111}$ Simon-Schnass ${ }^{109}$ identified significant increases in indirect indices of free radical mediated lipid peroxidation at altitude, which included increased pentane excretion and thiobarbituric acid reactive substances, decreased erythrocyte filterability, and increased leucocyte and granulocyte counts. Daily supplementation with an antioxidant such as tocopherol (vitamin $E$ ) equivalent to 300-400 mg has been shown to improve endurance performance, by theoretically limiting tissue damage. ${ }^{109110}$ An accelerated production of the highly toxic hydroxyl radical may occur as a consequence of an increased production of free iron derived from altitude induced and training induced destruction of red blood cells. ${ }^{11}$ Thus it would appear that hypobaric hypoxia significantly increases oxidative stress, which has been shown to negatively influence energy metabolism and membrane integrity. 


\section{Summary and future research}

Physiological acclimatisation to a chronically reduced $\mathrm{P}_{1} \mathrm{O}_{2}$ is a prerequisite to achieve optimal physical performance in environmental hypoxia. However, scientific evidence to support the claim that either continuous or intermittent hypoxic training will enhance sea level performance remains at present equivocal. Future research should focus on methodological technicalities that optimise the balance between the favourable and less favourable responses to hypoxia and potential mediators of performance after return to sea level. Preliminary evidence showing that the additive stress of hypobaric hypoxia may provoke an adverse immune response and further potentiate free radical mediated oxidative injury has important implications which, if confirmed by scientific rigor, would present a threat to both the fitness and health of the elite competitor.

Our research was supported by the British Olympic Association and the British Athletics Federation. We would also like to acknowledge Mr N Papps of Ordnance Survey, UK, and Mr S Greenberg for their keen assistance in collecting data contained in fig 1 .

1 Bert P. Barometric pressure: researches in experimental physiology Columbus, OH: College Book Co, 1943. (Translated by MA Hitchcock and RA Hitchcock.)

2 Smith MH, Sharkey BJ. Altitude training: who benefits? Physician and Sportsmedicine 1984;12:48-62.

3 Terrados $\mathrm{N}$. Altitude training and muscular metabolism. In f Sports Med 1992;13:S206-9.

4 Levine BD, Stray-Gundersen J. A practical approach to altitude training: where to live and train for optimal performance enhancement. Int $\Im$ Sports Med 1992;13:S209-12.

5 Levine BD, Roach RC, Houston CS. Work and training at altitude. In: Sutton JR, Coates G, Houston CS, eds Hypoxia and mountain medicine. Texas, VT: Queen City Printers, 1992:192-201.

6 Sutton JR. Exercise training at high altitude: does it improve endurance performance at sea-level? Sports Science Ex change 1993;6:4.

$7 \mathrm{Hahn}$ AG. The effect of altitude training on athletic performance at sea-level: a review. Sports 1993;13:1-7.

8 Saltin B. Exercise and the environment: focus on altitude. Res Q Exerc Sport 1996;67:1-10.

9 Wes $Q$ Exerc Sport 1996;67:1-10. Wolski LA, McKenzie DC, Wenger HA. Altitude training
for improvements in sea level performance. Is there for improvements in sea level performance. Is there

10 Stine TA, Levine BD, Taylor S, Schultz W, Stray-Gundersen J. Quantification of altitude training in the field [abstract] Med Sci Sports Exerc 1992;24:S103.

11 Young AJ, Young PM. Human acclimatization to high terrestrial altitude. In: Pandolf KB, Sawka MN, Gonzalez $\mathrm{PR}$, eds. Human performance physiology and environmental medicine at terrestrial extremes. Indianapolis: Benchmark Press, 1988:497-543.

12 Szygula Z. Erythrocytic system under the influence of physical training and exercise. Sports Med 1990;10:181-97.

13 Young A. Energy substrate utilization during exercise in extreme environments. Exerc Sport Sci Rev 1990;18:65-118.

14 Levine BD, Friedman DB, Engfred K, Hanel B, Kjaer M Clifford PS, Secher N. The effect of normoxic or hypobaric
hypoxic endurance training on the hypoxic ventilatory hypoxic endurance training on the hypoxic
response. Med Sci Sports Exerc 1992;24:769-75.

15 Shephard RJ. Problems of high altitude. In: Shephard RJ Astrand PO, eds. Endurance in sport. Oxford: Blackwell SciAstrand PO, eds. End

ence, 1992:471-8.
16 Meehan RT. Immune supression at high altitude. Ann Emerg Med 1987;16:974-9.

17 Schmidt W, Spielvogel H, Eckardt KU, Quintela A Penaloza R. Effects of chronic hypoxia and exercise on plasma erythropoetin in high-altitude residents. $\mathcal{f} A p p$ Physiol 1993;74:1874-8.

18 Gledhill N. The influence of altered blood volume and oxygen transport capacity on aerobic performance. Exerc Sports Sci Rev 1985;13:75-93.

19 Ekblom B, Berglund B. Effect of erythropoetin administration on maximal aerobic power. Scand $\mathcal{f}$ Sports Med 1991 1:88-93.

20 Metra M, Cannella G, La Canna G. Improvement in exercise capacity after correction of anemia in patients with end stage renal failure. Am 7 Cardiol 1991;68:1060-6.

21 Celsing F, Svedenhag J, Pilhstedt P, Ekblom B. Effects of anaemia and stepwise-induced polycythaemia on maximal aerobic power in individuals with high and low haemoglobin concentrations. Acta Physiol Scand 1987;31:47-54.
22 American College of Sports Medicine. Position stand on the use of blood doping as an ergogenic aid. Med Sci Sport Exerc 199628:i-viii.

23 Buick FJ, Gledhill N, Froese AB, Spriet L, Meyers EC. Effect of induced erythrocythemia on aerobic work capacity. F Appl Physiol 1980;48:636-42.

24 Spriet LL, Gledhill N, Froses AB, Wilkes DL, Meyers EC. The effects of induced erythrocythemia on central circulathe effects of induced erythrocythemia on central circulation and oxygen transport dur

25 Williams, MH, Wesseldine S, Somma T, Schuster R. The effect of induced erythrocythemia upon 5-mile treadmill effect of induced erythrocythemia upon 5-mile
run time. Med Sci Sports Exerc 1981;13:169-75.

26 Goforth HW, Campbell Jr NL, Hodgdon JA, Sucec AA Hematologic parameters of trained distance runners following induced erythrocythemia. Med Sci Sports Exerc 1982;14: 174

27 Robertson RJ, Gilcher R, Metz KF, Skrinar GS, Allison TG Bahnson HT, et al. Effect of induced erythrocythemia on hypoxia tolerance during physical exercise. $\mathcal{F}$ Appl Physio 1982;53:490-5.

28 Robertson RJ, Gilcher R, Metz KF, Caspersen CJ, Allison TG, Abbott RA, et al. Hemoglobin concentration and aerobic work capacity in women following induced erythrocythemia. $\mathscr{f} A p p l$ Physiol 1984;57:568-75.

29 Thompson JM, Stone JA, Ginsburg AD, Hamilton P. $\mathrm{O}_{2}$ transport during exercise following blood reinfusion. $\mathcal{F} A p p l$ Physiol 1982;53:1213-19.

30 Sawka MN, Dennis RC, Gonzalez RR, Young AJ, Muza SR Martin JW, et al. Influence of polycythemia on blood volume and thermoregulation during exercise-heat stress. $f$ Appl Physiol 1987;62:912-18.

31 Robertson RJ, Gilcher R, Metz KF, Caspersen CJ, Allison TG, Abbott RA, et al. Effect of simulated altitude erythrocythemia in women on hemoglobin flow rate during exercise. F Appl Physiol 1988;64:1644-9.

32 Dempsey JA, Reddan WG, Birnbaum ML. Effects of acute through life-long hypoxic exposure on exercise pulmonary gas exchange. Respir Physiol 1971;13:62-89.

33 Hochachka PW, Stanley C, Matheson GO, McKenzie DC Allen PS, Parkhouse WS. Metabolic and work efficiencies during exercise in Andean natives. $\mathcal{F}$ Appl Physiol 1991;70: $1720-30$.

34 Sun SF, Droma TS, Zhang JG, Tao JX, Huang SY, McCullough RG, et al. Greater maximal $\mathrm{O}_{2}$ uptake and vital lough RG, et al. Greater maximal $\mathrm{O}_{2}$ uptake and vital Physiol 1990;79:151-62.

35 Ge RL, Chen QH, Wang LH, Gen D, Yang P, Kubo K, Higher exercise performance and lower $\mathrm{VO}_{2} \max$ in Tibetan than $H a n$ residents at $4,700 \mathrm{~m}$ altitude. $\mathcal{F} A p p$ Physiol 1994;77:684-91.

36 Favier R, Spielvogel H, Desplanches D, Ferretti G, Kayser $B$, Hoppeler $H$. Maximal exercise performance in chronic hypoxia and acute normoxia in high-altitude natives. $\mathcal{f} A p p$ Physiol 1995;78:1868-74.

37 Huang SY, Sun S, Droma T, Zhuang J, Tao JX, McCullough RG, et al. Internal carotid arterial flow velocity during exer-
cise in Tibetan and Han residents of Lhasa $(3,658 \mathrm{~m}) . \mathcal{F}$ Appl Physiol 1992;73:2638-42.

38 Svedenhag J, Saltin B, Johansson C, Kaijser L. Aerobic and anaerobic exercise capacities of elite middle-distance runners after two weeks of training at moderate altitude. Scand F Med Sci Sports 1991;1:205-14.

39 Beall CM, Blangero J, Williams-Blangero S. Goldstein MC. Major gene for percent of oxygen saturation of arterial Major gene for percent of oxygen saturation of arterial 1994;95:271-6.

40 Niermeyer S, Yang $P$, Drolkar S, Zhuang J, Moore LG. Arterial oxygen saturation in Tibetan and Han infants born in Lhasa, Tibet. $N$ Engl ₹ Med 1995;333:1248-52.

41 Ward MP, Milledge JS, West JB. High altitude medicine and physiology. 2nd ed. London: Chapman and Hall Medical, 1995:344.

42 Levine BD, Stray-Gundersen J, Duhaime G, Snell PG Friedman DB. Living high-training low: the effect of altitude acclimatization/normoxic training in trained runners. Med Sci Sports Exerc 1991;23: [abstract145].

43 Ingjer F, Myhre K. Physiological effects of altitude training on elite male cross-country skiers. F Sports Sci 1992;10:37-47.

44 Mizuno M, Juel C, Bro-Rasmussen T, Mygind E, Schibye B, Rasmussen B, Saltin B. Limb skeletal muscle adaptation in Rasmussen B, Saltin B. Limb skeletal muscle adaptation in athletes

45 Faulkner JA, Daniels JT, Balke B. Effects of training at moderate altitude on physical performance capacity. $\mathcal{F} A p p l$ Physiol 1967;23:85-9.

46 Stray-Gundersen J, Mordecai N, Levine BD. $\mathrm{O}_{2}$ transport response to altitude training in runners. Med Sci Sports Exerc 1996;27(S5): [abstract 1131].

47 Loeppky JA, Bynum WA. Effects of periodic exposure to hypobaria and exercise on physical work capacity. $\mathcal{F}$ Sport Med Phys Fitness 1970;10:238-47.

48 Klausen K, Robinson S, Michael ED, Myhre LG. Effect of high altitude on maximal working capacity. $\mathcal{f}$ Appl Physiol 1966;21:1191-4.

49 Banister EW, Woo W. Effects of simulated altitude training on aerobic and anaerobic power. Eur $\mathcal{F}$ Appl Physio 1978;38:55-69.

50 Levine BD, Friedmann B, Stray-Gundersen J. Confirmation of the "high-low" hypothesis: living at altitude-training near sea level improves sea level per

51 Terrados N, Melichna J, Sylven C, Jansson E, Kaijser L. Effects of training at simulated altitude on performance 
and muscle metabolic capacity in competitive road cyclists. Eur $\mathcal{F}$ Appl Physiol 1988;57:203-9.

52 Terrados N, Jansson E, Sylven C,Kaijser L. Is hypoxia a stimulus for synthesis of oxidative enzymes and myoglobin? f Appl Physiol 1990;68:2369-72.

53 Asano K, Sub S, Matsuzaka A, Hirakoba K, Nagai J Kawaoka $T$. The influences of simulated high altitude training on work capacity and performance in middle and training on Sports Sciences 1986;9:195-202.

54 Klausen T, Mohr T, Ghisler U, Nielsen OJ. Maximal oxygen uptake and erythropoetic responses after training at uptake and erythropoetic responses after training

55 Asahina K, Ikai M, Agawas Y, Kuroda Y. A study on acclimatization to altitude in Japanese athletes. Schweizerishe Zeitschrift Fuer Sportmedizin 1966;14:240-5.

56 Faulkner JA, Kollias J, Favour CB, Buskirk ER, Balke B Maximum aerobic capacity and running performance at altitude. F Appl Physiol 1968;24:685-91.

57 Daniels J, Oldridge $\mathrm{N}$. The effects of alternate exposure to altitude and sea-level on world-class middle-distance runners. Med Sci Sports 1970;2:107-12.

58 Balke B, Nagle FJ, Daniels J. Altitude and maximum performance in work and sports activity. $\mathfrak{F} A M A$ 1965:194: $176-9$.

59 Dill DB, Adams WC. Maximal oxygen uptake at sea-level and at 3,090-m altitude in high school champion runners. $\mathcal{f}$ Appl Physiol 1971;30:854-9.

60 Reeves JT, Grover RF, Cohn JE. Regulation of ventilation during exercise at $10,200 \mathrm{ft}$ in athletes born at low altitude. during exercise at 10,200 ft in

61 Buskirk ER, Kollias J, Akers RF, Prokop EK, Reategui EP. Maximal performance at altitude and on return from Maximal performance at altitude and on return from
altitude in conditioned runners. $\mathcal{f}$ Appl Physiol 1967;23:
259-66.

62 Vallier JM, Chateau P, Guezennec CY. Effects of physical training in a hypobaric chamber on the physical performance of competitive triathletes. Eur $\mathcal{F}$ Appl Physiol 1996;73 $471-8$.

63 Rusko HK, Kirvesniemi H, Paavolainen L, Vahasoyrinki P Kyro KP. Effect of altitude training on sea level aerobic and anaerobic power of elite athletes. Med Sci Sports Exerc 1996;28(S5): [abstract 739].

64 Bailey DM, Davies B, Romer L, Gandy G. Physiological implications of moderate altitude training (1640 metres) on sea-level endurance performance in elite distance

65 Telford RD, Graham KS, Sutton JR, Hahn AG, Campbel DA, Creighton SW, et al. Medium altitude training and
sea-level performance. Med Sci Sports Exerc 1996;28(S5): sea-level perform

66 Adams WC, Bernauer EM, Dill DB, Bomar Jr JB. Effects of equivalent sea - level and altitude training on $\mathrm{VO}_{2} \mathrm{Max}$ and running performance. f Appl Physiol 1975;39:262-6.

67 Roskamm H, Landry F, Samek L, Schlager M, Weidemann $\mathrm{H}$, Reindell $\mathrm{H}$. Effects of a standardized ergometer training program at three different altitudes. F Appl Physiol 1969;27 840-7.

68 Levine BD, Engfred K, Friedman DB, Kjaer M, Saltin B, Clifford PS, Secher NH. High altitude endurance training: Sports Exerc 1990;22: [abstract 209].

69 Friedman DB, Levine BD, Hanel B, Engfred K, Clifford PS, Secher NH. Endurance training and the hypoxic ventilatory response. Med Sci Sports Exerc 1990;22(S99): [abstract $592]$.
Rahkil.

70 Rahkila $P$, Rusko $H$. Effects of high altitude training on muscle enzyme activities and physical performance characteristics of cross-country skiers. In: Komi P, ed. Exercise and
sport biology. Champaign, IL: Human Kinetics, 1982:143sport

71 Hahn AG, Telford RD, Tumilty DM, McBride ME, Campbell DP, Kovacic JC, et al. Effect of supplementary hypoxic training on physiological characteristics and ergomete performance of elite rowers. Excel 1992;8:127-38.

72 Favier R, Spielvogel D, Desplanches D, Ferretti G, Kayser $\mathrm{B}$, Grunenfelder A, et al. Training in hypoxia vs. training in normoxia in high-altitude natives. $\mathcal{F}$ Appl Physiol 1995;78: 2286-93.

73 Davies CT, Sargeant AJ. Effects of hypoxic training on normoxic maximal aerobic power output. Eur $\mathcal{F}$ Appl Physiol 1974;33:227-36.

74 Desplanches D, Hoppeler H, Linoissier MT, Denis C, Claassen $H$, Dormois $D$, et al. Effects of training in normoxia and normobaric hypoxia on human muscle normoxia and normobaric hypoxia on hum

75 Hansen JE, Vogel JA, Stelter GP, Consolazio CF. Oxygen uptake in man during exhaustive work at sea-level and high uptake in man during exhaustive work at
altitude. $₹ \mathrm{Appl}$ Physiol 1967;23:511-22.

76 Winslow RM, Monge CC. Hypoxia, polycythemia and chronic mountain sickness. Baltimore: John Hopkins University Press, 1987.

77 Milledge JS. High altitude. In: Harries M, Williams C, Stanish W, Micheli $\mathrm{L}$, ed. Oxford textbook of sports medicine. London: Oxford University Press, 1994:217-30.

78 Kayser B. Nutrition and energetics of exercise at altitude. Theory and possible practical implications. Sports Med 1994;17:309-23.

79 Saltin B. Aerobic and anaerobic work capacity at 2,300 metres. Medical Thoracics 1967;24:205-10.

80 Gore CJ, Hahn AG, Watson DB, Norton KI, Campbell DP, Scroop GS, et al. $\mathrm{VO}_{2} \mathrm{Max}$ and arterial $\mathrm{O}_{2}$ saturation at sea
- level and $610 \mathrm{~m}$. Med Sci Sports Exerc 1996;27(S5): [abstract 42]

81 Anselme F, Caillaud C, Courret I, Prefaut C. Exercise induced hypoxemia and histamine excretion in extreme athletes. Int $\mathcal{F}$ Sports Med 1992;13:80-1.

82 Lawler J, Powers SK, Thompson D. Linear relationship between $\mathrm{VO}_{2} \quad \mathrm{Max}$ and $\mathrm{VO}_{2}$ Max decrement during exposure to acute hypoxia. $\mathcal{F} A$ ppl Physiol 1988;64:146-9.

83 Koistinen P, Takala T, Martikkala V, Leppalouto J. Aerobic fitness influences the response of maximal oxygen uptake and lactate threshold in acute hypobaric hypoxia. Int $f$ Sports Med 1995;26:78-81.

84 Rowell LB, Taylor HL, Wang Y. Saturation of arterial blood with oxygen during maximal exercise. f Appl Physiol ogy $964 ; 19: 284-6$

85 Dempsey JA. JBWolffe memorial lecture. Is the lung built for exercise? Med Sci Sports Exerc 1986;18:143-55.

86 Nummela A, Jouste P, Rusko H. Effect of living high and training low on sea level anaerobic performance in runners. Med Sci Sports Exerc 199628(S5):[abstract 740].

87 Weil JV, Jamieson G, Brown DW, Grover RF. The red cell mass-arterial oxygen relationship in normal man. $f$ Clin Invest 1968;47:1627-39.

88 Shephard RJ, Bouhlel E, Vandewalle H, Monod H. Peak oxygen intake and hypoxia. Int $\mathcal{F}$ Sports Med 1988;9:279-83.

89 Dick FW. Training at altitude in practice. Int $\mathcal{F}$ Sports Med 1992;13:S203-5.

90 Berglund B. High-altitude training. Aspects of haematological adaptation. Sports Med 1992;14:289-303.

91 Rejnafarje C, Lozano R, Valdivieso J. The polycythemia of high altitudes: iron metabolism and related aspects. Blood 1959;14:433-55.

92 Hannon JP, Shields, JL, Harris CW. Effects of altitude acclimatization on blood composition of women. $\mathcal{f}$ Appl Physiol 1969;26:540-7.

93 Stray-Gundersen, Alexander C, Hochstein A, deLomos D, Levine BD. Failure of red cell volume to increase to altitude exposure in iron deficient runners. Med Sci Sports Exerc 1992;24(suppl):S90.

94 Suslov FP. Basic principles of training at high altitude. In New studies in athletics, The IAAF Quarterly Magazine for NSA 1994;2:45-9.

95 Benoit H, Costes F, Castells J, Busso T, Denis C, Lacour JR, Geyssant A. Endurance training in normobaric hypoxia: ventilatory response and ability to exercise. Int $\mathcal{\exists}$ Sports Med 199213:90[abstract]

96 Dill DB, Braithwaite K, Adams WC, Bernauer EM, Blood volume of middle distance runners: effect of $2300 \mathrm{~m}$ altitude and comparison with non-athletes. Med Sci Sports Exerc 1974;6;1-7.

97 Reilly T. Circadian rhythms. In: Harries, M, Stanish W, Micheli L, eds. Oxford textbook of sports medicine. London: Oxford University Press, 1994:238-54

98 Martino M, Myers K, Bishop P. Effects of 21 days training at altitude on sea - level anaerobic performance in competitive swimmers. Med Sci Sports Exerc 1996:27(S5): [abstract 37].

99 Nummela A, Jouste P, Rusko $H$. Effect of living high and training low on sea level anaerobic performance in runners. Med Sci Sports Exerc 1996;28(S5): [abstract 740].

100 Hogan MC, Welch HG. The effect of altered arterial oxygen tensions on muscle metabolism in dog skeletal muscle during fatiguing work. Am $₹$ Physiol 1986;251:C216-C222.

101 Wolfel EE, Groves BM, Brooks GA, Butterfield GE, Mazzeo RS, Moore LG, et al. Oxygen transport during steady-
state submaximal exercise in chronic hypoxia. $\mathcal{f} A p p l$ Physiol 1996;70:1129-36.

102 Boutellier U, Marconi C, diPrampero PE, Cerretelli P. Effects of chronic hypoxia on maximal performance. Clinical Respiratory Physiology 1982;18(S4):39-44.

103 Shephard RJ, Pang NS. Potential impact of physical activity and sport on the immune system: a brief review. Brit $\mathcal{F}$ Sports Med 1994;28:247-55.

104 Uchakin P. Immunological adaptations to altitude training [abstract]. In: The third world congress for sport science 1995: 209-210.

105 Klokker M, Kharazmi A, Galbo H, Bygberg I, Pedersen BK. Influence of in vivo hypobaric hypoxia on function of ymphocytes, neutrocytes, natural killer cells and cytokines. f Appl Physiol 1993;74:1100-6.

106 Meehan RT, Duncan U, Neale LS, Taylor G, Muchmore $\mathrm{H}$, Scott N, et al. Operation Everest II: alterations in the immune system at high altitudes. $\mathcal{f}$ Clin Immunol 1988;8: 397-406.

107 Parry-Billings M, Blomstrand E, Mc Andrew N, Newsholme E. A communicational link between skeletal muscle,
brain, and cells of the immune system. Int $\mathcal{f}$ Sports Med 1990;11(S2):S122-8.

108 Wagenmakers AJM. Amino acid metabolism, muscular Wagenmakers AJM. Amino acid metabolism, muscular high altitude. Int $\mathcal{f}$ Sports Med 199213:S110-13.

109 Simon-Schnass I. Risk of oxidative stress during exercise at high altitude. In: Sen CK, Packer L, Hanninen O, eds. Exercise and oxygen toxicity. Amsterdam: Elsevier, 1994;1 191-210.

110 Nagawa T, Kita H, Aoki J, Maeshima T, Shiozawa K. Asian Medicine 1968;11:619-33.

111 Biselli R, Pecci G, Oliva C Fattorossi A, D'Amelio R, Barsotti P. Effects of hypobaric hypoxia $(\mathrm{HH})$ on polymorphonuclear granulocytes (PMNL) respiratory activity in HH-acclimatized and non-acclimatized rats [abstract]. Int 千 Sports Med 1992;13:94. 